\title{
APLIKASI METODE BALANCED SCORECARD DALAM PENGUKURAN KINERJA LEMBAGA PENDIDIKAN TINGKAT MENENGAH
}

\author{
Roikhan*, Zeplin Jiwa Husada \\ Magister Teknik Industri, Fakultas Teknologi, Institut Teknologi Adhi Tama Surabaya \\ Email: roikhan.bgh@gmail.com ; zeplin.jhusada@gmail.com
}

Artikel masuk : 14-11-2019

Artikel direvisi : 03-12-2019

Artikel diterima : 21-12-2019

*Penulis Korespondensi

\begin{abstract}
Abstrak - Peningkatan kinerja pendidikan merupakan salah satu parameter dalam keberhasilan dalam mengelolah lembaga yang mempunyai orientasi terhadap pelayanan dalam penyelenggaraan pendidikan. MTS. $X$ merupakan lembaga pendidikan tingkat menengah berbasis pesantren yang berada dibawah yayasan pondok pesantren. Sebagai salah satu dunia usaha yang bergerak di bidang jasa terutama jasa pendidikan. MTs. $X$ berupaya meningkatkan kualitas pelayanan kepada pelanggan dan daya saing dengan lembaga-lembaga pendidikan lain yang sederajat. Tujuan penelitian ini adalah untuk mengukur kinerja di MTs. $X$ dengan metode Balanced Scorecard. Hasil penelitian menunjukan bahwa secara keseluruhan belum tercapainya kinerja yang maksimal lembaga pendidikan di Mts. $X$. Target efektivitas penggunaan keuangan $98,75 \%$ sedangkan realisasi penggunaan $80,59 \%$. Perspektif kepuasan peserta didik dengan 18 indikator pengukuran kinerja menunjukan masih kurang maksimal dengan nilai 3,93. Proses internal belum tercapai karena masih banyak kekurangan dari sarana dan prasarana, proses aktivitas kerja, dan rendahnya kepuasan kerja bagi tenaga didik. Pertumbuhan dan pembelajaran untuk memberikan motivasi, pengembangan diri, inovasi dan suasana kerja masih kurang diberikan oleh lembaga. Peningkatan kinerja lembaga pendidikan harus dilakukan untuk meningkatkan daya saing yang lebih kompetitif di masa yang mendatang. Lembaga sebaiknya melakukan perbaikan melalui pengembangan yang lebih inovatif dan pengukuran kinerja dengan pendekatan key performance indicator yang lebih luas sehingga mampu memberikan pelayanan yang maksimal.
\end{abstract}

Kata kunci: Balanced Scorecard; Kinerja; Lembaga Pendidikan; Strategi

\begin{abstract}
Improving educational performance is one of the parameters in the success in managing institutions that have an orientation towards service in the delivery of education. MTS. $X$ is a pesantren based secondary level educational institution which is under the boarding school foundation. As one of the business world engaged in services, especially education services. MTs. $X$ seeks to improve the quality of service to customers and competitiveness with other educational institutions that are equal. The purpose of this study is to measure performance in MTs. X with the Balanced Scorecard method. The results showed that overall the maximum performance of educational institutions in MTs had not yet been achieved. X. Target's effectiveness of financial use is $98.75 \%$, while the realization of application is $80.59 \%$. The student satisfaction perspective with 18 performance measurement indicators shows that it is still not optimal with a value of 3.93. he internal process has not been achieved because there are still many shortcomings of facilities and infrastructure, the process of work activities, and low job satisfaction for students. Growth and learning to provide motivation, selfdevelopment, innovation, and work atmosphere still lack by the institution. Improving the performance of educational institutions must be done to develop more competitive competitiveness in the future. Institutions should make improvements through more innovative development and performance measurement with a broader approach to key performance indicators to be able to provide maximum service..
\end{abstract}

Keywords: Balanced Scorecard; Educational Institutions; Performance; Strategies 


\section{PENDAHULUAN}

Dunia pendidikan memerlukan inovasi perbaikan dalam rangka mengembangkan ilmu pengetahuan, meningkatkan kompetensi dan kreativitas bangsa (Wu, Lin, \& Chang, 2011). Salah satu upaya perbaikan penyelenggaraan pendidikan adalah dengan melakukan reorientasi penyelenggaraan pendidikan melalui peningkatan kinerja (Julaiha, 2011). Mutu pendidikan yang diharapkan bukan hanya pada pencapaian target kurikulum semata, akan tetapi menyangkut kinerja semua yang turut menunjang tercapainya mutu pendidikan sekolah (Dally, 2010). Berdasarkan letak geografis dan demografis yang luas maka pendidikan di indonesia memerlukan perhatian pengelolaan yang lebih terstruktur dalam pelaksanaannya (Qur'ani Habib \& Machali, 2016). Program pembaharuan dengan sasaran peningkatan pertumbuhan partisipasi peserta didik yang bersifat terpusat mengakibatkan tidak fleksibel dalam penerapannya (Suyatno, Rusdarti, \& Sudana, 2016). Tercapainya kinerja lembaga pendidikan harus diukur melalui evaluasi dan kontrol terhadap pelaksanaan kerja lembaga tersebut (Julaiha, 2011).

Sebagai salah satu dunia usaha yang bergerak di bidang jasa terutama jasa pendidikan, maka MTs. $X$ berupaya meningkatkan kualitas pelayanannya kepada pelanggan dan daya saing dengan lembaga-lembaga pendidikan lain yang sederajat. Laporan keuangan yang diterapkan selama ini adalah Laporan Keuangan Terpusat (LKP), artinya bahwa bagian keuangan sekolah wajib melaporkan transaksi keuangan Madrasah kepada Pengurus Yayasan Pondok Pesantren setiap awal bulan. Faktor terjadinya penurunan perolehan peserta didik di MTs. $X$ antara lain adanya persaingan dari Lembaga Pendidikan yang lain. Untuk mengukur sistem penilaian kinerja dapat menggunakan model Balanced Scorecard (Lestari, 2013). Balanced Scorecard merupakan salah satu ukuran kinerja alternatif yang bertujuan untuk menggabungkan ukuran kinerja keuangan dan non keuangan. Balanced Scorecard mampu memberikan pemahaman yang tepat dan komprehensif kepada manajer tentang performance (Kaplan \& Norton, 1996). Metode ini menerjemahkan visi dan strategi entitas ke dalam berbagai tujuan dan ukuran melalui penyusunan perspektif keuangan, perspektif pelanggan, perspektif proses bisnis internal, serta perspektif pertumbuhan dan pembelajaran (Gambar 1) (Daud, Rahim, \& Kohar, 2018; Wijayanti, 2012).

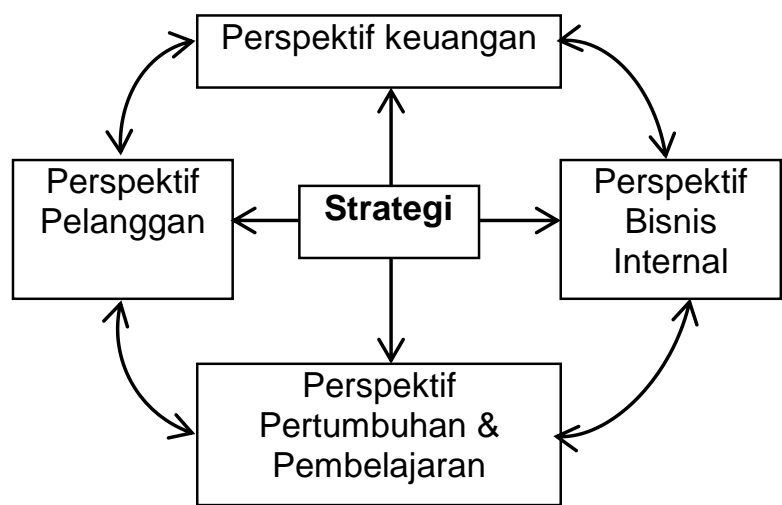

Gambar 1. Perspektif Balanced Scorecard

Pada dasarnya balanced scorecard merupakan sistem manajemen bagi suatu organisasi untuk berinvestasi dalam jangka panjang yang meliputi pelanggan (customer), pembelajaran dan pertumbuhan karyawan dan manajemen (learning and growth), sistem (internal business process), dan hasil-hasil finansial (financial) (Harsono, 2016)..Penilaian kinerja dengan menggunakan pendekatan balanced scorecard diharapkan dapat mengatasi kelemahan berbagai penilaian kinerja yang selama ini dilakukan oleh institusi pendidikan (Kusuma, 2017).

Pemilihan Balanced Scorecard sebagai metode pengukuran di Mts. $X$ berdasarkan literatur penelitian terdahulu, dimana Balanced Scorecard mampu mengukur dan mengevaluasi kinerja lembaga pendidikan (Papenhausen \& Einstein, 2006; Tohidi, Jafari, \& Afshar, 2010; Wu et al., 2011; Zangoueinezhad \& Moshabaki, 2011). Selain itu Balanced Scorecard dapat mengintegrasikan strategi perusahaan baik jangka pendek maupun jangka panjang.

Penelitian ini bertujuan untuk mengukur kinerja lembaga lembaga pendidikan di MTs. $X$ dengan metode Balanced Scorecard berdasarkan perspektif keuangan, pelanggan, proses bisnis internal, serta perspektif pertumbuhan dan pembelajaran. Hasil pengukuran diharapkan dapat sebagai referensi pihak lembaga pendidikan untuk perbaikan dan pengembangan kinerja pada tiap unit-unit lembaga pendidikan.

\section{METODE PENELITIAN}

Metode penelitian dibagi dalam beberapa tahapan. Tahap pertama menentukan variabel kuesioner dari masing-masing perspektif yang ada dalam balanced scorecard yaitu perspektif keuangan, perspektif kepuasan peserta didik, 
perspektif proses internal, perspektif pertumbuhan dan pembelajaran.

Tahap kedua yaitu penentuan populasi dan sampel penelitian. dengan menggunakan rumus slovin.

$n=\frac{N}{N(e)^{2}+1}$

Dimana:

$\mathrm{n}$ : ukuran sampel

$\mathrm{N}$ : ukuran populasi

e : Kelonggaran ketidaktelitian

Penelitian ini menggunakan tingkat kesalahan pengambilan sampel sebesar $10 \%$ dengan tingkat kepercayaan 90\%. Berdasarkan hasil pengumpulan data diperoleh jumlah peserta didik MTs. X 419 siswa. Maka jumlah sampel penelitian dapat diketahui sebesar $80,73 \approx 81$ responden.

Tahap ketiga penyusunan kuesioner dan penentuan skala pengukuran keuangan dan skala pengukuran kuesioner. Skala pengukuran keuangan dibagi menjadi 3 kategori efisiensi, ekonomis dan efektif (Tabel 1)

Tabel 1. Skala pengukuran perspektif keuangan

\begin{tabular}{ll}
\hline Skala & Kategori \\
\hline Efisiensi & Sangat Efisien \\
$<100 \%$ & Efisien \\
$100 \%-110 \%$ & Cukup Efisien \\
$110 \%-120 \%$ & Tidak Efisien \\
$120 \%-130 \%$ & Sangat Tidak Efisien \\
$>130 \%$ & \\
Ekonomis & Sangat Ekonomis \\
$<80 \%$ & Ekonomis \\
$80 \%-85 \%$ & Cukup Ekonomis \\
$85 \%-90 \%$ & Tidak Ekonomis \\
$90 \%-95 \%$ & Sangat \\
$>95 \%$ & Ekonomis \\
Efektif & \\
$>95 \%$ & Sangat Efektif \\
$80 \%-95 \%$ & Efektif \\
$65 \%-80 \%$ & Cukup Efektif \\
$50 \%-65 \%$ & Tidak Efektif \\
$<50 \%$ & Sangat Tidak Efektif \\
\hline
\end{tabular}

Pengukuran kinerja dengan metode Balanced Scorecard di MTs. X dengan kuesioner digunakan untuk mengukur kinerja pada perspektif kepuasan peserta didik, perspektif proses internal dan perspektif pertumbuhan dan pembelajaran. Penggunaan skala likert dengan data interval 1-5 untuk menunjukkan tingkat kepuasan responden yang diteliti. (1) Sangat Tidak Puas, (2) Tidak Puas, (3) Cukup Puas, (4) Puas, (5) Sangat Puas) . Sedangkan untuk nilai kinerja akhir balanced scorecard ditunjukan pada tabel 2.

Tabel 2. Skala kinerja akhir balanced scorecard

\begin{tabular}{ll}
\hline Nilai & Kategori \\
\hline$>90 \%$ & Sangat Baik \\
$80 \%-90 \%$ & Baik \\
$70 \%-80 \%$ & Cukup Baik \\
$60 \%-70 \%$ & Tidak Baik \\
$<60 \%$ & Sangat Tidak Baik \\
\hline
\end{tabular}

Hasil data penyebaran kuesioner diolah dengan menggunakan uji validitas dan reliabilitas. Tahap selanjutnya yaitu analisis pengukuran kinerja terhadap kondisi eksisting dengan menggunakan metode balanced scorecard yaitu perspektif keuangan, perspektif kepuasan peserta didik, perspektif proses internal, perspektif pertumbuhan dan pembelajaran. Tahap terakhir adalah penentuan scoring terhadap masing-masing perspektif untuk mengetahui nilai akhir kinerja.

\section{HASIL DAN PEMBAHASAN Perspektif Keuangan}

Anggaran Pengelolaan Keuangan (APK) dan Laporan Pengelolaan Keuangan (LPK) pada Tahun Pelajaran 2018-2019. Penilaian kinerja keuangan dimaksud dilakukan dengan value for money atas laporan keuangan yang menghitung efisiensi, ekonomi, dan efektifitas kondisi keuangan Madrasah. Berdasarkan Iaporan realisasi anggaran diperoleh jumlah pendapatan yang terealisasi sebesar Rp. 555.382.350,- atau 98,75 $\%$ dari target anggaran pendapatan yang ditetapkan oleh MTs. X sebesar Rp. 562.400.000,-Sedangkan untuk realisasi belanja operasional pada Tahun Pelajaran 2018-2019 mencapai Rp. 447.607.500, atau 88,98 \% dari total anggaran belanja sebesar Rp. 503.060.000,. Dari laporan realisasi anggaran tersebut, dengan metode analisis value for money maka dapat dicari tingkat keekonomian kondisi keuangan MTs. X

Nilai Ekonomis $=\frac{\text { Realisasi belanja operasional }}{\text { Anggaran belanja operasional }} \times 100$

Nilai Ekonomis $=\frac{447.607 .500}{503.060 .000} \times 100=88,98 \%$

Berdasarkan perhitungan tersebut didapat hasil tingkat keekonomian kondisi keuangan MTs. $X$ sebesar 88,98 \%, kondisi ini juga menunjukkan bahwa MTs. $X$ telah melakukan penghematan belanja operasional sebesar $\mathrm{Rp}$. 55.452 .500 atau $11,02 \%$ dari total anggaran belanja. Dengan menggunakan pengukuran 
skala pengukuran perspektif keuangan didapat hasil nilai ekonomis keuangan MTs. X sebesar 3 (nilai konversi) atau dapat dikategorikan cukup ekonomis.

Sedangkan efektivitas keuangan MTs. X dengan metode value for money sebagai berikut:

$$
\begin{aligned}
& \text { Nilai Efektif }=\frac{\text { Realisasi pendapatan usaha }}{\text { Anggaran pendapatan usaha }} \times 100 \\
& \text { Nilai Efektif }=\frac{555.382 .350}{562.400 .000} \times 100=98,75 \%
\end{aligned}
$$

Realisasi pendapatan usaha riil dari jasa layanan pendidikan di MTs. X terdapat selisih pendapatan usaha sebesar Rp. 7.017.650,-. Dengan tingkat efektifitas keuangannya sebesar 98,75 \%. Berdasarkan skala likert maka didapat hasil nilai efektifitas keuangan MTs. X sebesar 5 (nilai konversi) atau dapat dikategorikan sangat efektif.

Sedangkan nilai efisiensi dari laporan realisasi anggaran dengan menggunakan metode value for money juga dapat diketahui efisiensi kondisi keuangan MTs. $X$

Nilai Efisiensi $=\frac{\text { Realisasi belanja operasional }}{\text { Realisasi pendapatan usaha }} \times 100$

Nilai Efisiensi $=\frac{447.607 .500}{555.382 .350} \times 100=80,59 \%$

Dari perhitungan diatas, didapat nilai efisiensi MTs. X sebesar $80,59 \%$. Dengan menggunakan skala likert maka didapat nilai efisiensi MTs. $X$ sebesar 5 (nilai konversi) atau sangat efisien. Secara keseluruhan kinerja perspektif keuangan dianggap baik dengan nilai rata-rata sebesar 4,33 dengan nilai terendah sebesar 3 pada tolak ukur ekonomi keuangan MTs.X (Tabel 3).

\begin{tabular}{|c|c|c|c|}
\hline \multirow[b]{2}{*}{ No } & Tolak & \multicolumn{2}{|l|}{ Ukur } \\
\hline & $\begin{array}{l}\text { Perspektif } \\
\text { Keuangan }\end{array}$ & Nilai & Kategori \\
\hline 1 & Ekonomi & 3 & \\
\hline 2 & Efektif & 5 & \\
\hline 3 & Efisien & 5 & \\
\hline & Jumlah & 4,33 & Baik \\
\hline
\end{tabular}

Tabel 3. Nilai kinerja perspektif keuangan

\section{Perspektif Kepuasan Peserta Didik}

Untuk mengukur kinerja pada perspektif peserta didik digunakan kuesioner Service Quality, dimana kepuasan peserta didik terbagi menjadi lima dimensi, yaitu tangible, reliability, responsiveness, assurance dan empathy. Hasil pengukuran kepuasan peserta didik disajikan pada tabel 4.
Tabel 4. Pengukuran kepuasan peserta didik

\begin{tabular}{cc}
\hline No $\quad$ Indikator & $\begin{array}{c}\text { Rata- } \\
\text { Rata }\end{array}$ \\
\hline Wujud Fisik (tangibles) &
\end{tabular}

pembelajaran sudah baik dan lengkap

Kebersihan dan keindahan di dalam

kelas dan dilingkungan sekolah sudah

baik

Absensi, jurnal kelas dan perlengkapan

alat-alat tulis di kelas dilaksanakan

dengan baik dan lengkap

Cara berpakaian guru dan karyawan

sangat rapi dan berseragam Kehandalan (reliability)

Semua karyawan melayani kebutuhan peserta didik dengan baik dan adil

Bapak /lbu guru melaksanakan tugas mengajar tepat waktu

Bapak/lbu guru cara mengajarnya

sangat menarik dan bervariasi

Daya Tanggap (responsiveness)

Bapak/lbu guru selalu siap menjawab pertanyaan dari peserta didik dengan cepat dan tepat Bapak/lbu guru segera memberikan bantuan dengan tulus jika ada peserta didik yang mengalami kesulitan Semua karyawan tidak pernah melakukan kesalahan dalam melakukan pencatatan administrasi atau pembayaran

$$
\text { Jaminan (assurance) }
$$

Bapak/ibu guru memberikan rasa aman dan nyaman dalam kegiatan belajar mengajar

Guru dan karyawan bersikap ramah, sopan dan bersahabat dalam memberikan pelayanan pendidikan terhadap peserta didik

Bapak/ibu guru menerangkan pelajaran dengan sungguh-sungguh dan menimbulkan rasa percaya yang tinggi terhadap peserta didik

Semua karyawan sudah terampil dalam melaksanakan tugas untuk melayani peserta didik

$$
\text { Empati (empathy) }
$$

Bapak/ibu guru memberikan rasa aman dan nyaman dalam kegiatan belajar mengajar

Guru dan karyawan bersikap ramah, sopan dan bersahabat dalam memberikan pelayanan pendidikan terhadap peserta didik

Bapak/ibu guru menerangkan pelajaran dengan sungguh-sungguh dan menimbulkan rasa percaya yang tinggi terhadap peserta didik

Semua karyawan sudah terampil dalam melaksanakan tugas untuk melayani peserta didik 
Dari tabel 4 maka dapat dihitung nilai ratarata tingkat kepuasan peserta didik berdasarkan lima dimensi service quality, yang ditunjukan pada tabel 5 .

Tabel 5. Nilai perspektif kepuasan peserta didik

\begin{tabular}{llrll}
\hline No & $\begin{array}{l}\text { Variabel } \\
\text { Kepuasan } \\
\text { Didik }\end{array}$ & $\begin{array}{r}\text { Perspektif } \\
\text { Peserta }\end{array}$ & $\begin{array}{l}\text { Nilai } \\
\text { Rata- } \\
\text { rata }\end{array}$ & Kategori \\
\hline 1 & $\begin{array}{l}\text { Wujud Fisik (tangibles) } \\
\text { Kehandalan }\end{array}$ & 3,93 & \\
2 & $\begin{array}{l}\text { (reliabilitas) } \\
\text { Daya }\end{array}$ & 3,95 & Tanggap \\
(responsiveness) & 3,97 & \\
4 & Jaminan (assurance) & 3,87 & \\
5 & Empati (empathy) & 3,92 & \\
\hline & Jumlah & 3,93 & $\begin{array}{l}\text { Cukup } \\
\text { Puas }\end{array}$ \\
\hline
\end{tabular}

\section{Perspektif Proses Internal}

Penilaian kinerja pada perspektif proses internal dilakukan dengan cara menyebarkan kuesioner yang terdiri dari Guru dan Karyawan MTs. X dan didistribusikan secara acak tanpa membedakan adanya perbedaan jenis kelamin. Indikator yang digunakan adalah sarana prasarana, proses manajemen dan kepuasan kerja.

Berdasarkan tabulasi data kuesioner diperoleh rata-rata persepsi proses internal sudah baik dengan indikator tertinggi pada peningkatan karir dipengaruhi oleh kesungguhan dalam melaksanakan tugas dan disertai dengan gaji yang layak $(4,27)$ dan terendah pada kemampuan mengatasi hambatan dalam melaksanakan pekerjaan dengan nilai 3,62 (Tabel 6). Sebagian besar responden menyatakan cukup baik atas upaya Madrasah dalam mendukung sepenuhnya tujuan manajemen MTs. $X$ dengan nilai rata-rata tingkat kepuasan Guru dan Karyawan sebesar 3,92.

Nilai kinerja terendah erdapat pada perspektif proses internal tepatnya pada variabel sarana dan prasarana yaitu sebesar 3,87 . Kemudian hasil kuesioner perspektif kepuasan peserta didik terdapat pada variabel wujud fisik (tangible) mencapai nilai rata-rata sebesar 3,80 atau nilai paling rendah dari total responden. Kondisi demikian menunjukkan bahwa adanya persamaan persepsi antara peserta didik, guru dan karyawan dalam menilai sarana dan prasarana MTs.X yang dianggap masih kurang memadai.
Tabel 6. Pengukuran kinerja perspektif proses internal

\begin{tabular}{|c|c|c|}
\hline Item & Indikator & $\begin{array}{l}\text { Rata- } \\
\text { Rata }\end{array}$ \\
\hline \multicolumn{3}{|c|}{ Sarana dan Prasarana } \\
\hline 1 & $\begin{array}{l}\text { Pengecekan dan perbaikan } \\
\text { inventaris kantor dilakukan } \\
\text { secara berkala }\end{array}$ & 3,82 \\
\hline \multirow[t]{2}{*}{2} & Data/informasi yang & \\
\hline & $\begin{array}{l}\text { dibutuhkan dalam pekerjaan } \\
\text { dapat diperoleh dengan } \\
\text { mudah dan lengkap }\end{array}$ & 4,02 \\
\hline 3 & $\begin{array}{l}\text { Sistem komputerisasi sudah } \\
\text { cukup menunjang efisiensi } \\
\text { dan efektivitas dalam bekerja }\end{array}$ & 3,75 \\
\hline \multicolumn{3}{|c|}{ Proses } \\
\hline 5 & $\begin{array}{l}\text { Mampu mengatasi hambatan } \\
\text { dalam } \quad \text { melaksanakan } \\
\text { pekerjaan }\end{array}$ & 3,6 \\
\hline 6 & $\begin{array}{l}\text { Terdapat instruksi yang jelas } \\
\text { dari pimpinan dalam } \\
\text { melakukan pekerjaan }\end{array}$ & 4,15 \\
\hline 7 & $\begin{array}{l}\text { Mampu melaksanakan } \\
\text { kegiatan belajar mengajar } \\
\text { sesuai dengan kurikulum }\end{array}$ & 4 \\
\hline \multicolumn{3}{|c|}{ Kepuasan Dalam Bekerja } \\
\hline 9 & $\begin{array}{l}\text { Sudah merasa puas bertugas } \\
\text { di MTs. } X\end{array}$ & 4 \\
\hline \multirow[t]{2}{*}{10} & $\begin{array}{l}\text { Adanya penghargaan bagi } \\
\text { guru dan karyawan yang } \\
\text { berprestasi dan teguran bagi } \\
\text { guru dan karyawan yang } \\
\text { membuat kesalahan }\end{array}$ & 3,82 \\
\hline & $\begin{array}{l}\text { Adanya apresiasi dari } \\
\text { pimpinan } \\
\text { profesionalisme } \\
\text { bekerja }\end{array}$ & 3,8 \\
\hline \multirow[t]{2}{*}{12} & $\begin{array}{ll}\text { Peningkatan } & \text { karir } \\
\text { dipengaruhi } & \text { oleh }\end{array}$ & \\
\hline & $\begin{array}{lrr}\text { kesungguhan } & \text { dalam } \\
\text { melaksanakan tugas dan } \\
\text { disertai dengan gaji yang } \\
\text { layak }\end{array}$ & 4,27 \\
\hline
\end{tabular}

Tabel 7. Nilai kinerja perspektif proses internal

\begin{tabular}{llll}
\hline No & $\begin{array}{l}\text { Variabel Perspektif } \\
\text { Proses Internal }\end{array}$ & $\begin{array}{l}\text { Nilai } \\
\text { rata- } \\
\text { rata }\end{array}$ & Kategori \\
\hline 1 & $\begin{array}{l}\text { Sarana } \\
\text { Prasarana dan }\end{array}$ & 3,87 & \\
2 & $\begin{array}{l}\text { Proses Internal } \\
\text { Kepuasan Dalam }\end{array}$ & 3,92 & \\
3 & $\begin{array}{l}\text { Bekerja } \\
\text { Jumlah }\end{array}$ & 3,97 & \\
\hline & Jum & $\begin{array}{l}\text { Cukup } \\
\text { Baik }\end{array}$ \\
\hline
\end{tabular}




\section{Perspektif Pertumbuhan dan Pembelajaran}

Untuk menjelaskan perspektif pertumbuhan dan pembelajaran, maka ditetapkan empat variabel pertanyaan yang menjadi tolok ukur penilaian kinerja perspektif yaitu motivasi, kesempatan mengembangkan diri, inovasi, suasana dalam bekerja.

Tabel 8. Pengukuran perspektif pertumbuhan dan pembelajaran

\begin{tabular}{|c|c|c|}
\hline No & Indikator & $\begin{array}{l}\text { Rata- } \\
\text { Rata }\end{array}$ \\
\hline \multicolumn{3}{|c|}{ Motivasi } \\
\hline & $\begin{array}{l}\text { Insentif (uang tambahan gaji) } \\
\text { yang diberikan sebagai balas jasa } \\
\text { untuk pekerjaan yang dilakukan } \\
\text { sudah berjalan di manajemen } \\
\text { madrasah }\end{array}$ & 4,07 \\
\hline 2 & $\begin{array}{l}\text { Kebijakan pimpinan membuat } \\
\text { saya termotivasi untuk bekerja } \\
\text { dengan baik }\end{array}$ & 3,17 \\
\hline 3 & $\begin{array}{l}\text { Sistem penyegaran (refreshing) } \\
\text { yang diberlakukan manajemen } \\
\text { madrasah untuk mengatasi } \\
\text { kejenuhan dalam bekerja sudah } \\
\text { berjalan. }\end{array}$ & 3,85 \\
\hline \multicolumn{3}{|c|}{ Kesempatan Mengembangkan Diri } \\
\hline 4 & $\begin{array}{l}\text { Diberikan kesempatan bagi guru } \\
\text { dan karyawan untuk belajar dan } \\
\text { melanjutkan pendidikan kejenjang } \\
\text { yang lebih tinggi }\end{array}$ & 3,67 \\
\hline 5 & $\begin{array}{l}\text { Pimpinan selalu memberikan } \\
\text { dorongan kepada guru dan } \\
\text { karyawan untuk terus belajar dan } \\
\text { mengembangkan diri }\end{array}$ & 3,65 \\
\hline 6 & $\begin{array}{l}\text { Terdapat diklat-diklat secara } \\
\text { berkala bagi guru dan karyawan } \\
\text { dalam meningkatkan } \\
\text { pengetahuan dan keterampilan }\end{array}$ & 3,95 \\
\hline \multicolumn{3}{|c|}{ Inovasi } \\
\hline 7 & $\begin{array}{llr}\text { Kreatifitas guru dan } & \text { karyawan } \\
\text { sangat diperlukan } & \text { untuk } \\
\text { pengembangan } & \text { pendidikan } \\
\text { sekolah } & \end{array}$ & 3,95 \\
\hline 8 & $\begin{array}{l}\text { Pimpinan memberikan apresiasi } \\
\text { terhadap pemikiran baru yang } \\
\text { positif }\end{array}$ & 4,03 \\
\hline 9 & $\begin{array}{l}\text { Guru dan karyawan selalu } \\
\text { berinovasi untuk meningkatkan } \\
\text { kualitas pelayanan pendidikan }\end{array}$ & 4,05 \\
\hline \multicolumn{3}{|c|}{ Suasana Dalam Bekerja } \\
\hline 10 & $\begin{array}{l}\text { Adanya keterbukaan antara } \\
\text { sesama rekan maupun dengan } \\
\text { pimpinan dalam menyampaikan } \\
\text { pendapat }\end{array}$ & 3,9 \\
\hline 11 & $\begin{array}{l}\text { Sudah terjalin hubungan baik } \\
\text { antara pimpinan dengan bawahan } \\
\text { atau sesama guru dan karyawan }\end{array}$ & 4,15 \\
\hline 12 & $\begin{array}{l}\text { Adanya kerjasama tim dalam } \\
\text { menyelesaikan pekerjaan }\end{array}$ & 4 \\
\hline
\end{tabular}

Tabel 8. Nilai kinerja perspektif pertumbuhan dan pembelajaran

\begin{tabular}{lllll}
\hline No & $\begin{array}{l}\text { Variabel } \\
\text { Pertumbuhan } \\
\text { Pembelajaran }\end{array}$ & $\begin{array}{r}\text { Perspektif } \\
\text { dan }\end{array}$ & $\begin{array}{l}\text { Nilai } \\
\text { rata- } \\
\text { rata }\end{array}$ & Kategori \\
\hline 1 & $\begin{array}{l}\text { Motivasi (reward and } \\
\text { punishment) }\end{array}$ & 3,7 & \\
2 & $\begin{array}{l}\text { Kesempatan } \\
\text { mengembangkan diri }\end{array}$ & 3,76 & \\
3 & $\begin{array}{l}\text { Inovasi } \\
4\end{array}$ & Suasana dalam bekerja & 4,01 & \\
\hline & \multicolumn{1}{c}{ Jumlah } & 3,87 & $\begin{array}{l}\text { Cukup } \\
\text { Baik }\end{array}$ \\
\hline
\end{tabular}

Berdasarkan hasil analisis yang dilakukan melalui penilaian kinerja pada 4 perspektif, secara keseluruhan masih belum tercapainya kinerja yang maksimal lembaga pendidikan di Mts. X (Tabel 8). Hal ini ditunjukan dengan realisasi target pendapatan diinginkan dengan tingkat efektivitas penggunaan keuangan $98,75 \%$ akan tetapi capaian realisasi penggunaan dana keuangan hanya sebesar $80,59 \%$ masih dibawah target realisasi pendapatan keuangan. Sedangkan perspektif kepuasan peserta didik dengan 18 indikator sebagai pengukuran kinerja rata-rata kinerja menunjukan kategori cukup puas dengan nilai rata-rata 3,93 yang menunjukan masih kurang maksimal pelayanan yang diberikan oleh lembaga (Tabel 9). Proses internal yang diukur dengan tiga variabel menunjukan bahwa belum tercapai karena masih banyak kekurang dari sarana dan prasarana, proses aktivitas kerja, rendahnya kepuasan kerja bagi tenaga didik. Pertumbuhan dan pembelajaran untuk memberikan motivasi, pengembangan diri, inovasi dan suasana kerja masih kurang diberikan oleh lembaga. Oleh karena peningkatan kualitas pendidikan merupakan salah satu ukuran keberhasilan lembaga pendidikan dalam mengelola manajemen untuk menperoleh pengukuran kinerja sesuai kebijakan yang ada (Rahman \& Singgih, 2012).

\section{KESIMPULAN}

Hasil pembahasan secara keseluruhan dari empat perspektif yang telah dilakukan diketahui bahwa penggunaan dana keuangan hanya mampu terealisasi sebesar $80,59 \%$ dari target penggunaan sebesar $98,75 \%$, kepuasan peserta didik terhadap pelayanan yang diberikan lembaga masih rendah dengan nilai rata-rata 3,93 sehingga perlu adanya perbaikan melalui program kerja berkelanjutan. Proses internal belum tercapai maksimal sehingga perlu perbaikan untuk menunjang kinerja guru dan karyawan. Pertumbuhan dan pembelajaran 
secara timbal balik belum tercapai dengan baik. Peningkatan kinerja lembaga pendidikan harus dilakukan untuk meningkatkan daya saing yang lebih kompetitif di masa yang akan datang. Lembaga harus selalu melakukan perbaikan melalui pengembangan yang lebih inovatif dan pengukuran kinerja dengan pendekatan key performance indicator yang lebih luas sehingga mampu memberikan pelayanan yang maksimal.

\section{DAFTAR PUSTAKA}

Dally, D. (2010). Balanced Scorecard suatu pendekatan dalam implementasi Manajemen. Bandung: Remaja Rosdakarya.

Daud, M., Rahim, A., \& Kohar, A. (2018). Strategi Peningkatan Kinerja Sekolah SMA Berbasis Balanced Scorecard Pada Yayasan Pendidikan Madania Indonesia. Jurnal Manajemen, $9(1), \quad 23$. https://doi.org/10.32832/jm-uika.v9i1.1271

Harsono, O. (2016). Pengaruh Strategi Bisnis dan Strategi Teknologi Informasi Terhadap Kinerja Lembaga Pendidikan: Studi Kasus Perguruan Islam Al-Izhar Pondok Labu. Telematika MKOM, 2(1), 52-58.

Julaiha, S. (2011). Balanced Score Card (BSC) sebagai Alternatif Pengukuran Kinerja Lembaga Pendidikan. Dinamika IImu, 11(2), $1-12$.

Kaplan, R. S., \& Norton, D. P. (1996). The Balanced Scorecard: Translating Strategy Into Action. Boston, Massachusetts: Harvard Business School Press.

Kusuma, V. (2017). Pengukuran Kinerja Balanced Scroecard (BSC) Pada Yayasan SMA Pawyatan Daha Kediri. Skripsi. Universitas Negeri Maulana Malik Ibrahim Malang.

Lestari, A. S. (2013). Analisis Penilaian Kinerja Lembaga Pendidikan Tinggi Dengan Metode Balanced Scorecard: Penerapannya Dalam Sistem Manajemen Strategis (Studi Kasus Pada Universitas Brawijaya Malang). In 2nd International Seminar on Quality and Affordable Education (ISQAE).

Papenhausen, C., \& Einstein, W. (2006). Implementing the Balanced Scorecard at a college of business. Measuring Business Excellence, 10(3), 15-22. https://doi.org/10.1108/1368304061068575 7

Qur'ani Habib, A., \& Machali, I. (2016). Efektivitas Penerapan Manajemen Berbasis Sekolah dalam Perspektif Balanced Scorecard Terhadap Mutu Pembelajaran Siswa Kelas XI dan Kelas XII di MAN Maguwoharjo
Sleman. Jurnal Pendidikan Islam, 1(2), 213-232.

Rahman, A., \& Singgih, M. L. (2012). Perencanaan Pengukuran Kinerja Di Lembaga Pendidikan Walisongo-Gempol Dengan Menggunakan Balanced Scorecard Dan Analytic Hierarchy Process ( AHP ). In Prosiding Seminar Nasional Manajemen Teknologi XVI (pp. 1-7).

Suyatno, Rusdarti, \& Sudana, I. M. (2016). Implementasi Balanced Scorecard Dalam Pengukuran Kinerja Manajemen Berbasis Sekolah. Educational Management, 5(2), 176-185.

Tohidi, H., Jafari, A., \& Afshar, A. A. (2010). Using balanced scorecard in educational organizations. Procedia - Social and Behavioral Sciences, 2(2), 5544-5548. https://doi.org/10.1016/j.sbspro.2010.03.904

Wijayanti, R. (2012). Analisis Kinerja RSUD DR. ISKAK Tulungagung dengan Metode Balanced Scorecard. Thesis, MPKP-FEUI, Tidak Dipublikasikan.

Wu, H.-Y., Lin, Y.-K., \& Chang, C.-H. (2011). Performance evaluation of extension education centers in universities based on the balanced scorecard. Evaluation and Program Planning, 34(1), 37-50. https://doi.org/10.1016/j.evalprogplan.2010. 06.001

Zangoueinezhad, A., \& Moshabaki, A. (2011). Measuring university performance using a knowledge-based balanced scorecard. International Journal of Productivity and Performance Management, 60(8), 824-843. https://doi.org/10.1108/1741040111118221 5 